\title{
THE INTERNATIONAL LEGAL STATUS OF FORMOSA ${ }^{1}$
}

Claude S. Phillips, Jr.

University of Michigan

$\mathrm{N}$

UMEROUS statements, official and unofficial, have been made in the past ten years purporting to describe the legal status of Formosa. It has been charged that Chaing Kai-shek has no claim to the island because he is "merely a fugitive quartering his army" there and besides, his is a government-in-exile." A reputable journalist maintains that "Chiang is juridically sovereign where he does not rule and he is not sovereign where he does." 3 Another famous journalist asks the question: "How many know ... that Formosa doesn't belong to Nationalist China any more than it does to Red China?" " Arthur H. Dean has suggested that Formosa is unclaimed territory (terra nullius); ${ }^{5}$ both the governments of Nationalist China and Communist China claim, as did President Truman in 1945, that Formosa is Chinese territory "liberated" by World War II; ${ }^{6}$ and President Eisenhower has stated that Formosa is "in the friendly hands of our loyal ally, the Republic of China." 7

These views all suggest a legal as well as political issue, and it is the purpose of this article to discuss some of the legal aspects. ${ }^{8}$ It is not sug-

${ }^{1}$ All references to Formosa will, unless otherwise indicated, refer also to the Pescadores. In spite of the recent change in State Department nomenclature from "Formosa" to "Taiwan," the former will generally be used in this paper since only recent references consistently use the latter term. See New York Times, January 22, 1956, sec. 4, p. 2, col. 5.

${ }^{2}$ Detroit Free Press, April 29, 1955, p. 8, col. 1. Cf. the statement by the Council on Foreign Relations, The United States in World Affairs, 1950 (New York: Harper \& Bros. for the Council on Foreign Relations, 1951), p. 26, to the effect that "by late 1949 ... the United States found itself in some danger of being left practically alone in continuing to recognize the fugitive Nationalist regime on the island of Formosa. ..."

${ }^{3}$ Walter Lippmann, New York Herald Tribune, April 28, 1955, p. 20.

"Mark Ethridge, "The U.S. Press is in Trouble: A Publisher's Diagnosis," Saturday Review, April 30,1955, p. 10. Ethridge added that "Chiang Kai-shek is there as an interloper."

5 "United States Foreign Policy and Formosa," Foreign Affairs, XXXIII (1955), 373.

${ }^{a}$ For Nationalist views see Han Lih-wu, Taiwan Today (Taipeh: Hwa Kuo Pub. Co., 1951), Foreword; and various statements by the representative of Nationalist China to the United Nations, UNSC, Doc. S/PV. 506 (September 26, 1950), p. 22; S/PV. 482 (August 29, 1950), S/PV. 503, 504, 505, 507. For Communist China's claim see United Nations Year Book, 1950, pp. 287-93; and A Guide to New China (Peking: Foreign Languages Press, 1953), pp. 39, 41. For Truman's statement see A Decade of American Foreign Policy, Basic Documents, 1941-49, Senate, 81st Cong., 1st Sess., Doc. No. 123 (Washington, D.C.., 1950), pp. 628, 694.

'Department of State Bulletin, February 7, 1955, p. 211.

${ }^{8}$ Perhaps the best works dealing with the political aspects of Formosa are those by Arthur Dean, loc. cit., and Joseph W. Ballantine, Formosa: A Problem for United States Foreign Policy (Washington, D.C.: Brookings Institution, 1952). Cf. also, Edwin O. Reischauer, Wanted: An Asian Policy (New York: Knopf, 1955); W. W. Rostow and Richard W. Hatch, An American Policy in Asia (New York: Wiley, 1955); and Harold M. Vinacke, The United States and the Far East, 1945-1951 (Stanford: Stanford University Press, 1952). 
gested that the following presents the only legal solution to the problem of the status of Formosa. Rather it is submitted here that at least one solution to the question of Formosa has been generally ignored. This is the argument that Formosa, by virtue of conquest and prescription, belongs to China and that the question of which China is a matter of recognition distinct from the question of the legal status. For a schema it seems appropriate first to review the facts concerning actual relinquishment by Japan of control over Formosa as well as the prevalent views of the United States as to the legal status of that island from 1945 to 1950 . Following is an examination of developments after the outbreak of the Korean conflict. Finally, a discussion of the legal status of Formosa in a critical examination of various terminology used in reference to that island is attempted.

\section{I}

Apparently the United States during World War II reserved for itself the right to determine what was to be done with Formosa after the war. The only clear, although unofficial, published account of the thinking in the Department of State about the future of Formosa during the war seems to be recorded in the writing of Joseph W. Ballantine, who was at the time the director of the Office of Far Eastern Affairs in the Department. ${ }^{9}$ Ballantine says that by the spring of 1944 it had been decided that Formosa was to be occupied by military forces and that plans had progressed to the point where the Navy rather than the Army would be responsible for the task. The State Department at this time was in possession of information that China was making preparations to take over the island. "Nevertheless," he adds, "it was considered that, while the participation of Chinese as individuals and in an advisory capacity would be welcomed, the United States should not ask the Chinese Government to take part in the administration." 10 Before a top-level decision could be taken on the State Department view, the military decided to bypass Formosa and seize Okinawa as the staging area for the final assault on Japan. With this development, Ballantine continues:

A general consensus seems to have been reached by the planners that only if Formosa were taken by United States forces in the course of combat operations would it be necessary to establish a military government there, and that in such event the island should be turned over to the Chinese as soon as this could be arranged without awaiting the formalization by treaty of Chinese sovereignty over the island. It was also envisaged that if an American military government was not established in consequence of combat operations, Formosa would be occupied and administered by the Chinese from the outset. ${ }^{11}$

\footnotetext{
"Ballantine, op. cit. Ballantine admits that the "available documentary material on the ... sequence of events [in 1944-45] is fragmentary," and that his account is based on his own recollections and those of Army and Navy officers and officials of the State Department whom he consulted while preparing his book (p. $57 \mathrm{n}$ ).

${ }^{10}$ lbid., p. 55.

${ }^{11}$ Ibid., pp. 56-57.
} 
Furthermore, the United States assumed that if China were given the control of Formosa, the island would immediately be made a province of China. ${ }^{12}$ In spite of these views, however, Ballantine asserts that the United States was unwilling to make any public pronouncement on the sovereignty of Formosa, apparently because there was not a clear-cut view to be presented. ${ }^{13}$

There is nothing in official records to discredit Ballantine's impressions. The State Department stated after the war that the administration of Formosa "was taken over from the Japanese by Chinese forces assisted by small American teams" pursuant to surrender terms dated September 2, 1945.14 The Supreme Commander of the Allied Forces received instructions on November 1, 1945, that he was to "treat Formosan-Chinese and Koreans as liberated peoples in so far as military security permits." ${ }^{15}$ President Truman, in a statement in December, 1945, and again a year later, referred to areas "liberated" from Japan and included in this term the island of Formosa. ${ }^{16}$ Furthermore, the President tied this idea of liberation in with the Cairo Declaration which referred to Formosa, among others, as territory which Japan had "stolen" from China. ${ }^{17}$ There is little doubt, in fact, that the United States regarded Formosa, after September, 1945, as being an integral part of China. When the Chinese began to administer Formosa as a province, the United States made no objections. ${ }^{18}$ Ambassadors and Foreign Service officers in their dispatches treated Formosa as a part of China. ${ }^{19}$ As recently as January 5, 1950, President Truman interpreted the United Nations resolution (of December 8,1949 ) calling on all states to refrain from seeking special rights or privileges "within the territory of

${ }^{12} \mathrm{Ibid}$., p. 58. This raises the question how, if the legal status was not yet perfect, Formosa could nevertheless be fully incorporated into China as a legal subdivision.

${ }^{13}$ lbid., p. 54.

${ }^{14}$ United States Relations with China, Department of State Publication No. 3573 (1949), pp. 307-08: hereinafter referred to as China White Paper. Han Lih-wu, former Nationalist Minister of Education, in his Taiwan Today, p. 3, marks September 2, 1945, as the date of the "Formal retrocession" of Formosa to China. Cf. H. M. Bate, Report from Formosa (New York: Dutton, 1952), p. 275.

15 "Basic Initial Post-Surrender Policy, Directive to Supreme Commander for the Allied Powers for the Occupation and Control of Japan, November 1, 1945," A Decade of American Foreign Policy, 1941-49, p. 640.

${ }^{16}$ Department of State Bulletin, December 16, 1945, pp. 945-46. Cf. also an oral statement of September 14, 1945, by Truman to Dr. T. V. Soong, China White Paper, p. 939.

${ }^{17}$ Ibid., p. 945.

${ }^{18}$ See China Handbook, 1951 (Taipeh, Taiwan: China Pub. Co., 1951), pp. 2, 3, 332, 338. Cf. Blair Bolles, "Vacillations Hamper U.S. Policy in Far East," Foreign Policy Bulletin, XXIX (August 11, 1950), 2. Note also that the United Nations Year Book, 1946-1947, p. 863, without qualification, listed Formosa as part of China.

"See statement by John Stewart Service in China White Paper, p. 565, for a reference to Formosa as one of the "national groups" of China; and to statements by Ambassador Stuart (ibid., pp. 936-37) and General Wedemeyer (ibid., pp. 759-60) which referred to Chiang's as the "central government" of Formosa. Stuart also referred to Formosa as a Chinese province, ibid., p. 938. 
China" as having "specific application ... with respect to Formosa." 20 In applying the China Aid Act of $1948,{ }^{21}$ the United States Government apparently made no attempt to distinguish Formosa from any other part of China. ${ }^{22}$ In a special guidance paper, dated December 23, 1949, sent by the State Department to Foreign Service officers around the world it was stated that "Formosa, politically, geographically, and strategically, is part of China. .. Politically and militarily it is a strictly Chinese responsibility." 23

The foregoing is by way of demonstrating that before the beginning of the Korean conflict the official position of the United States concerning the legal status of Formosa was that the island was (and had been since September, 1945) an integral part of China. ${ }^{24}$ In keeping with this approach the Truman Administration, before June, 1950, maintained a hands-off policy towards the "civil conflict" in China, particularly as it concerned Formosa. ${ }^{25}$ Furthermore, the State Department guidance paper referred to above stated in 1949 that the loss of the island "is widely anticipated," and emphasized the point that the United States had no "responsibilities or obligations, actual or moral" therein. ${ }^{26}$ It seems certain, therefore, that the attitude of the United States in June, 1950, was that Formosa was historically Chinese territory, that it had been "liberated" from Japan and returned to its owner, and that matters affecting Formosa were strictly Chinese domestic affairs. ${ }^{27}$

II

Apparently there were many others nations in the world which felt the same way as did the United States, but their attitudes did not become so well known as that of the United States until after the outbreak of the Korean conflict. Yet it was this very conflict which was the occasion of the change of attitude on the part of the United States.

Immediately on the outbreak of the Korean conflict on June 25, 1950, the "civil" conflict in China apparently became, for the Truman Adminis-

${ }^{20}$ A Decade of American Foreign Policy, 1941-49, p. 727.

${ }^{21} 62$ Statutes at Large 158.

${ }^{22}$ China White Paper, pp. 1006, 1017, 1028, 1032.

${ }_{23}$ "Policy Information Paper - Formosa," Military Situation in the Far East, Hearings before the Committee on Armed Services and the Committee on Foreign Relations, United States Senate, 82d Cong., 1st Sess., Part 3, pp. 1667-68: hereinafter referred to as Military Situation in the Far East.

${ }^{24}$ In fact on January 5, 1950, Truman said that in fulfillment of the Cairo and Potsdam Declarations, "Formosa was surrendered to Generalissimo Chiang Kai-shek and for the past four years the United States and the other Allied Powers have accepted the exercise of Chinese authority over the Island." A Decade of American Foreign Policy, $1941-49$, p. 728.

${ }^{25}$ Ibid.

${ }^{26}$ See Military Situation in the Far East, p. 1668.

${ }^{2}$ This is not to say that there were no dissenting views from important quarters in the United States. See the China White Paper, 309, 1032; Military Situation in the Far East, p. 1668; and a statement by Senator Elbert Thomas, 95 Cong. Rec. 3137 (1949). 
tration, an "international" conflict. On June 27 the President said that the Korean conflict was "a direct threat to the security of the Pacific area to United States forces performing their lawful and necessary functions in that area." Accordingly, Mr. Truman "ordered" the Seventh Fleet to "prevent any attack on Formosa" and "called upon" the "Chinese Government on Formosa" to cease air and sea operations against the mainland. Furthermore, as if to emphasize that this was not merely a request from one independent nation to another, he added the ominous words, "The Seventh Fleet will see that this is done." ${ }^{28}$ And if further evidence of the changed attitude be needed, the President also raised the question of the "future status" of Formosa and said that would have to await "the restoration of security in the Pacific, a peace settlement with Japan, or consideration by the United Nations." 29 In the meantime, he implied, the United States was holding this question in abeyance, "in the interest of the essential security of all." 30

The (Communist) Central People's Government reacted quite differently, of course, charging the United States with aggression. When invited by the United Nations to state its case, the essence of its argument was that Formosa was de jure as well as de facto an integral part of China on the grounds that the Chinese Government had "exercised sovereignty over the island" as a result of the Cairo Declaration, the Potsdam Declaration, and the Japanese terms of surrender. Furthermore, the Communists argued that no one had questioned the fact that "Taiwan was an inseparable part of Chinese territory de jure and de facto" before June 1950. ${ }^{31}$ Finally, they argued that the United Nations had no right whatsoever to alter that status by virtue of Article 107 of the Charter. ${ }^{32}$

By the time of the Japanese Peace Conference in September, 1951, at least two approaches to the legal status of Formosa existed: (1) that Formosa had been returned to China and the peace treaty could do no more than confirm this, and (2) that the legal status was unclear and that its

${ }^{3}$ Department of State Bulletin, July 3, 1950, p. 5.

${ }^{2}$ Ibid. Cf. also Acheson's admission that there was a changed attitude, as well as the assertion that United States forces were in Japan, the Ryukyus and the Philippines "as of right" but in Formosa in conformity with obligations under the United Nations. Military Situation in the Far East, pp. 1729, 1763-64, and 1812-13.

${ }^{30}$ Department of State Bulletin, July 31, 1950, p. 166.

${ }^{31}$ United Nations Year Book, 1950, pp. 288-92.

32 This provides that: "Nothing in the present Charter shall invalidate or preclude action, in relation to any state which during the Second World War has been an enemy of any signatory to the present Charter, taken or authorized as a result of that war by the Governments having responsibility for such action."

For the various arguments on the issue (including the inference by the United States that Chiang was on Formosa, not because of the Cairo Declaration, but merely as a representative of the victorious Allies in the Pacific), see United Nations Year Book, 1950, pp. 293-98. 
status might be cleared up by the peace treaty or by the United Nations or by some other international action.

Unfortunately, the peace treaty did not clear up the issues. Japan merely renounced "all right, title and claim to Formosa" as well as to the Kurile Islands and Southern Sakhalin, without in any case listing a beneficiary. ${ }^{33}$ Nor did the debate at San Francisco help matters. In fact, in spite of earlier hopes that the question of legal status might be resolved by the peace treaty, apparently this hope was abandoned by the United States even before the Conference, for no attempt was made there (except by the three Communist powers) to indicate a beneficiary of Japan's renunciations.

Furthermore, it was quite clear by 1951 that the ultimate solution to the debate over Formosa would have to be one acquiesced in by the United States - for that country had obviously, and unilaterally, stepped in as a protector of the island.

It might be thought that the Eisenhower Administration, on the slogans of "liberation" and "unleashing of Chiang," would have altered this situation. In truth, it may really have helped to clear up the matter to some extent by entering into a treaty with the "Republic of China," the essential territory of which was listed as Formosa. ${ }^{34}$

The treaty itself provides, in Article II, that both parties will act individually and collectively "to resist armed attack and communist subversive activities directed from without against their territorial integrity and political stability." Now it might be presumed that since the conflict in China from 1945 to 1949 was a civil one, an attack by the Chinese Communists would not be "from without." Partly in order to make it clear that such was not the case, ${ }^{35}$ Article VI specifically states that "for the purposes of Articles II and V, the terms 'territorial' and 'territories' shall mean in respect of the Republic of China, Taiwan and the Pescadores ..." and such other territories as may be determined by mutual agreement. Thus it might well appear that the United States, by entering into a treaty with a nation whose only territory was Formosa and the Pescadores plus some minor islands, was in effect recognizing that the rule over those territories was not only de facto but de jure. The Senate, however, refused to accept any such implication, for the Foreign Relations Committee inserted in its report the following: "It is the understanding of the Senate that nothing in the present treaty shall be construed as affecting or modifying the legal status or the sovereignty of the territories referred to in Article VI." 36

\footnotetext{
${ }^{33}$ See Article 2, Conference for the Conclusion and Signature of the Treaty of Peace with Japan, Department of State Publication No. 4392, p. 314: hereinafter referred to as Japanese Peace Conference.

${ }^{34}$ Department of State Bulletin, December 13, 1954, p. 895.

3 Thus in effect recognizing two Chinas.

${ }^{36} 101$ Cong. Rec. 1168 (February 9, 1955).
} 
The Senate "understanding" apparently intended to take no stand on the legal issue, but merely to maintain the status quo, whatever that happened to be, before the treaty was signed. But in actuality, the Senate merely confused matters. For if the Nationalist Government is not "sovereign" in Formosa, then the United States entered into a treaty with a "government" without territory, raising in fact a possibility which the United States Government had not heretofore even hinted at, namely that Chiang's may be a "government-in-exile." ${ }^{37}$ On the other hand, if Chiang is "sovereign" on Formosa, and all other territory is "without," then this raises the clear possibility of their being two Chinas.

\section{III}

The legal status of Formosa has certainly been shrouded in vague and often mysterious language. So far Formosa has been referred to as "stolen" territory which has been "liberated" and returned to China; as territory legally returned to China in accordance with the terms of the Cairo and Potsdam Declarations; as territory taken over by the aggression of the United States Seventh Fleet to be administered by the ousted former government of China; as territory whose legal status would be determined by the Japanese peace treaty; as territory whose legal status would have to be determined by some international arrangement, probably through the United Nations; and as terra nullius. It has been further asserted that the Nationalist Government is the legitimate government of China pushed by civil conflict into one of its provinces, namely Formosa; that it is a government which has been popularly repudiated by revolution; that it has been illegally aided in holding on to part of Chinese territory which belongs to the victorious Chinese masses; that it is a government-in-exile (on territory whose "sovereignty" is either in doubt or else which belongs by virtue of Japan's surrender and the Japanese peace treaty to the victorious Pacific Allies or to the United Nations, or to some other international grouping or arrangement). An examination of some of these concepts appears warranted.

Formosa as "stolen" and "liberated" territory. It is submitted that these terms have, in relation to Formosa, no legal meaning or significance. It is difficult to imagine how territory legally ceded in 1895 to Japan, ${ }^{38}$ and recognized in 1922 in the Four Power Treaty as being a part of Japan, ${ }^{39}$

\footnotetext{
${ }^{37}$ Besides the reference supra, p. 276, to Chiang's as a government in exile, cf. also Arthur Dean, loc. cit., p. 373; and Claude A. Buss, The Far East (New York: Macmillan, $1955)$, p. 571 .

${ }^{a s}$ In fact the United States participated in bringing Japan and China together in the arrangements. See Foreign Relations (1895), Part II, p. 969; and Payson J. Treat, Diplomatic Relations Between the United States and Japan, 1895-1905 (Stanford: Stanford University Press, 1938), p. 1.

${ }^{39} 43$ Statutes at Large 1646, 1652; Foreign Relations of the United States, 1922 (Washing, ton: Government Printing Office, 1938), I, 33, 46. Parties to this treaty were the United States, Japan, France, and the British Empire. China at this time requested
} 
could be regarded in any legal sense as "stolen." It was hardly illegal in 1895 to gain territory by conquest and if title to such can be questioned then a Pandora's box of challenges to title to all other territories so acquired (such as part of the southwestern United States taken from Mexico only fifty years earlier) is opened. Clearly, the term "stolen" as used in the Cairo Declaration has no legal meaning.

"Liberation" suffers the same fate. While the term "liberation" apparently has military meaning (in reference to territory first lost then regained in the course of conflict) and even political meaning (in reference to objectives of governments to see unfriendly regimes deposed), it does not appear to have any legal meaning whatsoever.

The references to Formosa as having been "stolen" and "liberated," therefore, can only have political (i.e., nonlegal) meaning. It is submitted, although no evidence has been found to indicate that this was a conscious policy of the Government, that these terms were employed in relation to Formosa in order to avoid the terms of the Atlantic Charter by which the United Nations, in waging World War II, agreed that they would "seek no aggrandizement, territorial or other." ${ }^{40}$ Obviously aggrandizement has occurred if territory legally belonging to the vanquished is taken by one of the victors. Hence, the subterfuge that Formosa did not belong to Japan.

Formosa as terra nullius. To regard Formosa as terra nullius borders on the preposterous. It is a generally recognized principle of international law that land areas, in order to be terra nullius, must be (1) uninhabited, or (2) inhabited by individuals who are not permanently united for political action, or (3) abandoned by former occupants, or (4) forfeited because they have not been occupied effectively. ${ }^{41}$ None of these possibilities even remotely relates to Formosa. It will be an unfortunate and confusing innovation to try to make the term terra nullius a political one (meaning apparently, in this context, territory title to which a foreign state is unwilling to recognize as belonging to the state or government which exercises effective control thereof). ${ }^{42}$ In truth, there is no justification whatsoever for making

that treaties affecting its territories should provide for obligations on the part of other states to respect its territorial integrity (which resulted in the Nine Power Treaty), but made no claim that Formosa was included in this term, and did not protest the Four Power Treaty. Ibid., pp. 272-74.

Cf. Quincy Wright, The Existing Legal Situation as it Relates to the Conflict in the Far East (New York: Institute of Pacific Relations, 1939), pp. 40, 65, and "The Chinese Recognition Problem," 49 American Journal of International Law 323 (1955).

${ }^{40}$ A Decade of American Foreign Policy, 1941-49, pp. 1-3.

${ }^{41}$ M. F. Lindley, Acquisition and Government of Backward Territory in International Law (London: Longmans, 1926), p. 80. Cf. also the sources cited in Herbert W. Briggs, The Law of Nations (New York: Appleton-Century-Crofts, 1952), pp. 250-51.

${ }^{42}$ Arthur Dean, loc. cit., pp. 372-73, comes suspiciously close to treating Formosa as terra nullius in this proposed political sense, if such is possible. He could have avoided this difficulty to saying that Chiang's China had Formosa by conquest, which has nothing to do with terra nullius. Cf. Green H. Hackworth, A Digest of International Law (Washington, D.C.: Government Printing Office, 1940-44), I, 427. 
it a political term, for the same effects can be obtained from a policy of nonrecognition. And as a legal concept, the term terra nullius has no applicability at all to Formosa.

Cairo and Potsdam Declarations as a legal basis of sovereignty over Formosa. Professor Quincy Wright has asserted that "the Japanese surrender [based on the Cairo and Potsdam Declarations] was not a definitive renunciation of the islands but a commitment to renounce them in the Treaty of Peace." "43 He fails to emphasize, however, that Japan actually did renounce its title. Clearly then Formosa does not belong to Japan if peace treaties taking territory (legally acquired) away from the yanquished are still internationally legal. Furthermore, it appears certain that Formosa was turned over to China in 1945, not merely in anticipation of Japan's renunciation, but clearly with the idea that Formosa was lost to Japan and would thenceforth belong to China.

The Nationalist Government as a government-in-exile. Two requirements seem necessary for a government to be in exile: the exile must be temporary and it must be on allied (foreign) territory, not on domestic territory. ${ }^{44}$ Chiang's residency is hardly temporary and it would be difficult, if not impossible, to assert that he is on foreign territory. There seems, therefore, to be no basis for regarding his as a government-in-exile.

Formosa as a part of China held by the de jure Government due to the intervention of the United States in China's civil conflict. The view that Formosa is a part of China retained by the Nationalists through the intervention of the United States in China's civil conflict, though espoused by the Communists, appears to be near the truth. That is not to say, however, that the action of the United States in intervening in the conflict was illegal. This question apparently is unsettled, for while the historical view has been that international law does not forbid a state to aid the legally recognized government of another state to put down insurrection, ${ }^{45}$ some

43 "The Chinese Recognition Problem," loc. cit., p. 332.

* Hans Kelsen, Principles of International Law (New York: Rinehart, 1952), p. 288. Cf. F. E. Oppenheimer, "Governments and Authorities in Exile," 36 American Journal of International Law 568 (1942); Sir Arnold D. McNair, Legal Effects of War (3rd ed.; Cambridge: The University Press, 1948), p. 355; Ernst Wolff, "The International Position of Dispossessed Governments at Present in England," 6 Modern Law Review, 208-15 (1942-43); State of Netherlands v. Federal Reserve Bank, S.D.N.Y. (1951), 99 F. Supp. 655; and Anderson v. Transandine, 289 N.Y. 9; 43 N.E.2d 502 (1942).

${ }^{45}$ See J. W. Garner, "Questions of International Law in the Spanish Civil War," 31 Amerir can Journal of International Law 68 (1937); L. F. L. Oppenheim, International Law - A Treatise, ed. H. Lauterpacht (7th ed.; New York: Longmans, 1952), II, 232; N. J. Padelford, International Law and Diplomacy in the Spanish Civil Strife (New York: Macmillan, 1939), p. 176; J. B. Moore, The Collected Papers of John Bassett Moore (New Haven: Yale University Press, 1945), VI, 443; and Briggs, op. cit., pp. 992, 999. 
authorities say that there is developing in international law the idea that no aid should be given to either side in a civil conflict. ${ }^{46}$

While the Truman policy appears to have been merely one of aiding a legal government to resist insurrection, the question remains whether the Eisenhower policy, in the Mutual Defense Treaty of December, 1954, was doing the same thing or actually attempting to stabilize the status quo. It would appear that the latter was intended, for the treaty speaks of attacks by Communists against Formosa as being "from without." The conclusion appears warranted that the United States has intervened in China's civil conflict in aid of the legally recognized government and has furthermore agreed to defend that government against any attacks from outside $\mathrm{Na-}$ tionalist China's present position. Since its present position is limited chiefly to one of its former provinces, apparently the remainder of what were its former provinces are to be regarded as lost to the legally recognized government and an attack from them on the former will be regarded as from without, that is, as an international, not a civil, incident. (Whether Quemoy and Matsu are "without" apparently poses a different problem to be jointly resolved by the United States and the Republic of China if and when a Communist attack requires it.)

Formosa as territory whose legal status must be determined by some international arrangement. As noted, there have been suggestions that Formosa's legal status might be settled (after the Japanese peace treaty) through "consideration by the United Nations," or by some "international action," or by "ultimate validation by the Allied Powers with whom Japan concluded the [peace] Treaty." "47 In view of the fact that the Nationalist Government, as the representative of China on the Security Council, has the power of veto, it is difficult to see how the United Nations can actually settle the legal status of Formosa. ${ }^{48}$

\footnotetext{
${ }^{46}$ See McNair, "The Law Relating to the Civil War in Spain," 53 Law Quarterly Review 491 (1937); C. C. Hyde, International Law Chiefly as Interpreted and Applied by the United States (Boston: Little, Brown, 1945), I, 253; C. G. Fenwick, International Law (New York: Appleton-Century-Crofts, 1948), pp. 244-45; Philip C. Jessup, Modern Law of Nations (New York: Macmillan, 1950), p. 53.

${ }^{47}$ Wright, "The Chinese Recognition Problem," loc. cit., p. 332. Wright suggests that the "claims of the de facto occupant, the government of Chiang Kai-Shek, were acquiesced in" by the peace treaty, even though two of the Pacific Allies (China and the Soviet Union) did not sign the treaty.

${ }^{18}$ For an excellent summary of this issue, see Benjamin $\mathrm{H}$. Brown and Fred Greene, Chinese Representation: A Case Study in United Nations Political Affairs (New York: Woodrow Wilson Foundation, September, 1955), p. 39 and passim.

Wright, loc. cit., p. 333, offers the possibility that "The parties to the Japanese Peace Treaty, most of whom are Members of the United Nations, are free under the Charter, which would legally prevail over the Cairo Declaration, to dispose of Formosa and the Pescadores according to the principle of self-determination rather than to restore them to China according to the policy declared at Cairo." In the very next paragraph, however, Wright reveals the unreality of any attempt to give Formosa to any other power than the Nationalists which, since the Nationalists already control
} 
The Pacific Allies, outside of the United Nations, might attempt to solve the problem, although the legal basis of their attempting to dispose of the only territory which one of the members of the Security Council has appears very weak indeed..$^{49}$ Of course there is always the problem of which China was the Pacific Ally. Until that is resolved apparently only the status quo will obtain. If that problem could be resolved to the satisfaction of all concerned then apparently there would be no legal problem.

There is one type of international negotiation presently occurring which is making a decided attempt to settle the legal status of Formosa once and for all. This is the negotiations between the United States and Communist Chinese ambassadors at Geneva. While both sides are appealing to legal arguments they seem to be doing so because their respective legal arguments reflect vital political objectives. Both sides are, at the date of this writing, apparently agreed to renounce the use of force in settling their international disputes. The very real political nature of the conflict becomes apparent, however, when Formosa comes into the picture. The United States has insisted that the renunciation of force must apply "particularly in the Taiwan area," while the Communists insisted that renunciation of force could not apply in relation to one's own territory and added categorically that

Formosa, weakens respect for any so-called objective legal solution to the island's status. Wright says that:

"These considerations suggest that there is no principle of international law which would prevent the parties to the Japanese Peace Treaty and the United Nations from recognizing the government of Chiang Kai-Shek as the government of a new state of Formosa and the Pescadores, if by a plebiscite or other means it is found that such a disposition corresponds to the wishes of the inhabitants of these islands."

Professor Wright does not suggest what could be done in case a plebiscite proved unfavorable to Chiang or how the Security Council, with Chiang's veto, could "dispose" of Formosa in any other way than by recognizing it as belonging to the $\mathrm{Na}$ tionalists.

Furthermore, the United States has made an attempt to get the General Assembly to consider the general situation of Formosa, but that body was unable to take any action whatsoever and adjourned sine die. United Nations Yearbook, 1951, p. 262.

All of the above difficulties may have prompted Arthur Dean to say that "from a legal standpoint" he did not see why or how the United Nations could formally settle the legal status of Formosa. Proceedings, American Society of International Law, April 28-30, 1955, p. 96. He further pointed out that if the United Nations could somehow establish a trusteeship over Formosa, the Nationalist Government would cease to exist "through total loss of territory." Ibid., p. 94.

Cf. also Vinacke, op. cit., p. 122, who observed that: "It is this control of Formosa which has given the principal support to the National Government's claim to continued recognition and to China's seat in the Security Council and other United Nation's organs. But it has made this claim as the government of China and not as the government of Formosa. ..."

40 In discussing the United States' proposal that the General Assembly consider "the general situation with respect to Formosa," the Nationalist representative said that "it was unprecedented in the United Nations for the Government of one Member state to question the right of another State to its territorial possessions." United Nations Year Book, 1950, p. 297.

Cf. also the argument of the Soviet Union that China had been permitted to accept the surrender of Japan on Formosa "on the legal ground that Taiwan was an inalienable part of Chinese territory." 
"Taiwan is Chinese territory." 50 Thus while each side is relying on legal principles for its approach to this issue the actual legal status of Formosa remains unchanged. These negotiations, however, have one real advantage - should an agreement actually occur in line with one or the other position advocated, then the legal picture would be cleared somewhat. Formosa would either become part of Communist China (thus affirming the Cairo Declaration that it be returned to China), or else Formosa would continue to exist apart from Communist China (thus affirming the idea that China's conflict of 1945-49 produced two Chinas and their relations are now international rather than internal). In either case Formosa's legal position will not be very different from the de facto situation of the last ten years; that is, it will still have been first, territory taken from Japan and given to China, then part of China torn by civil strife, then finally either reincorporated into China under a revolutionary government or permanently formed into a new Chinese state administered by the former government of China. That is to say, the legal status will result from political agreements all of which apparently will merely confirm that Formosa is Chinese territory, regardless of which China is meant. An "international solution," therefore, of the type now being attempted, will tend to do no more than affirm some form of Chinese sovereignty, either Nationalist or Communist. It appears doubtful that Formosa, through the Geneva negotiations, will be given to any non-Chinese state or group of states. ${ }^{51}$

Conclusion. The positions and attitudes discussed above all seem incomplete as an explanation of the legal status of Formosa. The real problem stems, not from present legal difficulties, but from political considerations during the war which ignored legal principles. While it may well be argued that some time after World War I it became internationally illegal to acquire territory by conquest, it is an indefensible argument to assert that such an acquisition was illegal as early as 1895 . Until some decades ago, conquest was certainly a legal method of obtaining title to territory. ${ }^{52}$ On this basis, Formosa in 1945 had been Japanese territory for half a century.

\footnotetext{
E0 See "Text of U.S. Statement of Geneva Negotiations with Chinese Reds over Taiwan," New York Times, January 22, 1956, pp. 12-13.

${ }^{51}$ An instructive discussion on the political nature of this topic occurred in the Senate debate over President Eisenhower's request for congressional approval of the use of United States armed forces to protect Formosa and the Pescadores. See 101 Cong. Rec., 627-28, 648-52 (January 26, 1955).

Cf. also Richard L. Walker, China Under Communism (New Haven: Yale University Press, 1955), p. 321: "The American defense of Taiwan has not been entirely altruistic. Taiwan is supported for strategic military reason and because of the important role it plays in countering Communist designs on Southeast Asia as well as on Japan. Nevertheless, having recognized the Nationalist government as the sovereign government of China, the United States is living up to its obligations under the Cairo Declaration that Taiwan should be turned over to the Chinese government."

${ }^{52}$ Hackworth, op. cit., I, 427.
} 
Recent developments in international law have cast doubts on the legality of title acquired by conquest. A series of international agreements and both official and unofficial pronouncements - the League Covenant, the Washington Conference of 1922, the Pact of Paris, League condemnation of Japan, Italy, and Russia - had by 1940 created the opinion in much of the world that acquisition of territory by force was illegal. In keeping with this belief the adherents to the Atlantic Charter renounced "aggrandizement, territorial or other" in their waging of World War II, and postwar developments under the Charter of the United Nations have reaffirmed this principle - the Korean conflict being the most dramatic incident to date.

In spite of these developing principles the victorious allies did take part of Japan's territory and turn it over to the de facto control of China. It has been argued, however, that the de jure status of Formosa is unclear. This argument, it is submitted, does not further respect for law. In the face of all the evidence (the Chinese incorporation of Formosa as a province without objection by other powers, the continued, uninterrupted, "sovereign" exercise of authority by a Chinese government, the claim by a successful insurgent Chinese government to that part of China not yet under its control - namely Formosa), it seems unfortunate and unnecessarily confusing to maintain that the facts are contrary to law and therefore to insist that the confusion must be settled by law when obviously the de facto situation of Formosa's being under Chinese rule will continue to obtain. As Wright has pointed out, a disharmony between a de facto and a de jure situation has been soon removed "by the general recognition of the de facto situation, thus giving it a de jure status." 53

The legal status of Formosa, it is submited, no longer rests on the Cairo and Potsdam Declarations or even upon the Japanese peace treaty, but rather upon the recognition policies of various governments in the world i.e., whether they recognize the Nationalist Government as now existing in one of its former provinces, or whether they recognize the insurgent govern-

\footnotetext{
${ }^{63}$ Wright, op. cit., p. 16. For a further discussion see Ballantine, op. cit., pp. 195-96.

It is no argument, it is submitted, to say that since Japan did not name a beneficiary in renouncing title to Formosa therefore the legal status of Formosa is uncertain roday. See Duncan Hall, Mandates, Dependencies and Trusteeships (Washington, D.C.: Carnegie Endowment for International Peace, 1948), p. 39.

The separate peace treaty between Japan and the Republic of China, signed at Taipeh, April 28, 1952 (U.N.T.S., Vol. 138, No. 1858 (1952)), contained in Article II a similar renunciation to that made in the peace treaty signed at San Francisco. The separate peace treaty, however, made references which appeared to recognize the authority of the Republic of China over Formosa. See especially Atticle X, as well as the accompanying protocol [Article 2(d)], exchange of notes and Agreed Minutes.

Although the treaty nowhere states that Formosa belongs to the Republic of China, that country was nevertheless careful to create the impression that Japan at least regarded Formosa as being under the control and jurisdiction of the Republic of China and that such control was not conditional.
} 
ment of the Chinese Communists. ${ }^{54}$ In connection with the latter is the further question of whether the recognizing governments hold that the Communists, by virtue of the general success of their revolution, are automatically entitled to Formosa or not. (It would seem that insurgents are not entitled ipso facto to more territory than they have been able to take over, at least as long as the legitimate government itself holds part of the original territory. ${ }^{55}$ ) The present legal problem today, therefore, appears to this writer to be concerned with reconciling the positions of the opposing blocs of governments on the question of recognition and not with the question of who holds title to Formosa. The problem of recognition, it is submitted, will not be solved on the results of World War II, but on the lines of a strictly political compromise looking to the avoidance of war in the Pacific.

In sum, this writer agrees with a suggestion by Arthur Dean (which the latter apparently does not fully accept himself) to the effect that "Nationalist China may have already acquired legal title to Formosa and the Pescadores by occupation or possibly by subjugation." 56 Furthermore, there appears to be no legal argument today which could deprive China of Formosa. Which China may, and will be, disputed, but that Formosa's legal status today is that it is Chinese territory seems indisputable. ${ }^{57}$ If conquest was not a legal means of acquiring territory in 1945, then it would seem that Formosa is still Japanese territory. To make such an assertion in the face of Japan's renunciation would raise legal problems which, fortunately, no nation has yet seemed willing to face.

\footnotetext{
${ }^{54}$ Cf. the statement by Werner Levi, Modern China's Foreign Policy (Minneapolis: University of Minnesota Press, 1953), p. 295, to the following effect: "The Cairo Declaration was implemented when the United States forces enabled the legitimate government of China to accept the surrender of the Japanese and establish a Chinese administration on Formosa. This administration has not been interfered with by the United States or any other foreign power. That this de facto control over Formosa could not be turned into de jure sovereignty was due to differences in policy among the foreign powers regarding the recognition of the National and the Communist governments."

${ }^{55}$ See Jessup, op. cit., p. 53.

${ }^{56}$ Proceedings, American Society of International Law, April 28-30, 1955, p. 96.

${ }^{5 \tau}$ As a final observation, it must be noted that the status of Formosa, vis-à-vis its transfer from Japan to China, and subsequent Japanese renunciation to title was identical to that of the cases of Southern Sakhalin and the Kuriles which were transferred from Japan to the Soviet Union.
} 